\author{
L.F. Ilyina, A.B. Ishmukhametova \\ Ye.A. Buketov Karaganda State University \\ (E-mail: anna.ishmuhametova@mail.ru)
}

\title{
Scientific bases of elementary physics course as an example of electrostatics
}

\begin{abstract}
The article describes a technique of teaching of electrostatics on the first and second stages learning the students of physics at school. To improve the quality of education offered to use complex methods and means of activating the cognitive activity of students and develop their cognitive interest. For better quality and assimilation, the theme given of high complexity tasks. The use of interactive equipment increases the visibility of the material, raises the interest of students can improve memorization of educational material. The above article analyzes the theoretical material allows you to organize a new, non-traditional learning activities, depending on the task in class.
\end{abstract}

Key words: electrostatics, Coulomb's law, Gauss theorem, polarization of dielectrics, electrostatic field.

Development of informative interest of the problem is caused by problems of modern society, preoccupied with preparing the younger generation to the active life. Physics as a subject forms the primary idea of the modern picture of the world is able to develop cognitive interests and creative abilities of students, their attitudes and beliefs, i.e., It promotes the education of highly moral person.

Relevance of the thesis consists in need of development of the receptions and means, which are stirring up cognitive activity of pupils. In a concrete case for studying of the subject «Electrostatics» use of the interactive equipment and the software corresponding to him is offered during studying of all subject in general. Both for carrying out lessons of lectures, and for lessons the solution of tasks, fixing and generalizations of material, laboratory researches. At the second stage of studying of this section there is a need provided by the program, considerations of some more difficult subjects of an electrostatics at the level of physical and mathematical, i.e. profile classes. What demands use of high school literature and its processing.

Work purpose: development of a technique of carrying out classes in an electrostatics as on the first and at the second step of studying of subjects I have undressed, and in higher education institution, with application of interactive technologies of the school students who are stirring up cognitive activity at lessons.

The novelty of the work consists in new role of the teacher in the classroom: he becomes organizer of independent informative activity of pupils, a competent advisor and assistant, helping students to overcome the difficulties encountered in the work.

Section «Electrostatics» in a school course of physics - this is one of the difficult parts.

After a detailed analysis of the topic «Electrostatics» in the basic physics course, we have selected and organized the relevant topic theoretical material studied in the first phase of training of pupils in schools.

In the first stage of the study of electrostatics, special importance is attached to the visibility of the material, since no serious laws can be no question. The concepts of electrodynamics, the electric charge and its main characteristics, types of charges and their interaction; the concept of electrification, electrifying ways. Considered one of the basic laws of electrostatics - the law of conservation of electric charge and Coulomb's law.

One of the fundamental laws of nature is the law of conservation of electric charge. This law established experimentally for the electrically isolated (closed) systems. Electrically isolated system is a system of bodies, electric charges are not communicating with the surrounding space.

The law of conservation of electric charge is formulated as follows: in a closed system, the algebraic sum of the charges of bodies remains constant [1]. The law is a mathematical expression:

$$
q_{1}+q_{2}+q_{3}+\ldots q_{n}=\text { const. }
$$

The law of interaction of electric charges has been experimentally established French physicist Charles Coulomb in 1785. In their experiments, Coulomb measured the force of attraction and repulsion of light charged beads through their specially designed instrument - torsion balance (Fig. 1). Torsion balance is an extremely high sensitivity. For example, the balance beam by a force of about $10^{-9} \mathrm{~N}$ is rotated to $1^{\circ}$. 


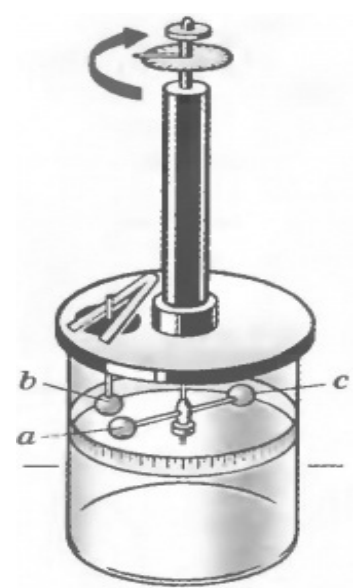

$a$ - small metal ball; $b$ - ball fixed on a rod attached to the lid of the balance; $c$ - counterweight

Figure 1. Model of the torsion balance

Using the method was performed weighing charge changes several times. If a charged ball brought into contact with the exact same unloaded ball, the first ball the charge is divided equally between the two balls. In experiments measured the interaction between pendant balls with dimensions much smaller than the distance between them (for example, $1 \mathrm{~mm}$ in radius). If the distance between the bodies is many times their size, any shape, size or charged substances is not significantly affect the interaction between them. These charged bodies are called point charges.

If you change the value of the charge of beads it was found that the strength of the interaction is proportional to the product of the module values of the charges:

$$
F \approx\left|q_{1}\right| \cdot\left|q_{2}\right| .
$$

When you change the distance between the interacting charged balls in two to three times the force of interaction has decreased or increased in four, nine times that It varies inversely with the square of the distance between the points charged bodies:

$$
F \approx \frac{1}{r^{2}} .
$$

Comparing both results, Pendant set the following pattern: the force between two electric charges is directly proportional to the product of modules interacting point charges and inversely proportional to the square of the distance between them, i.e.

$$
F \approx \frac{\left|q_{1}\right| \cdot\left|q_{2}\right|}{r^{2}} .
$$

This wording expresses the interaction between the fixed point electric charges, which was later called Coulomb's law [2]. Mathematically, Coulomb's law is written in a vacuum in the form of:

$$
F_{0}=k \frac{\left|q_{1}\right| \cdot\left|q_{2}\right|}{r^{2}},
$$

where $F_{0}$ - the force of interaction of point charges in a vacuum; $\left|q_{1}\right|$ and $\left|q_{2}\right|$ - modules interacting charges; $r$ - the distance between the charges; $k$ - coefficient of proportionality depending on the choice of the system of units used in the formula.

Coulomb's law - the fundamental law of electrostatics. Electrostatics - electrodynamics section in which we study the properties and interactions of fixed relative to the selected frame or bodies charged particles. With the help of modern experimental methods scientists have determined that at distances of $10^{-15}$ meters to tens of kilometers and violation of Coulomb's law is not observed.

Concepts of electrostatic field and its main characteristics - strength and capacity, the relationship between power and energy characteristics of the electrostatic field, a graphical representation of an electrostatic field. Electrostatic field - is a special kind of matter through which passed the action charged substances to others.

The power characteristic of the field produced by the charge of $q$, is the ratio of the force acting on the charge to the amount of this charge is called electrostatic voltage, i.e.,

$$
\vec{E}=\frac{\vec{F}}{q_{\text {test. }}}=\frac{q}{4 \pi \varepsilon_{0} r^{3}} \cdot \vec{r}
$$

where $\vec{E}$ - the intensity of the electrostatic field; $\vec{F}$ - the force exerted by the electrostatic field on the test charge $q_{\text {test }}$.

In order to describe the electric field strength vector must be set in each point of the field. This can be done graphically or analytically. To do this, use the power lines - a line tangential to that at any point of the field coincides with the direction of tension $\vec{E}$ (Fig. 2). Typically, when a graphic image of the field lines of force density determines the magnitude of the intensity vector. This one line of force per unit area perpendicular to the line corresponds to a unit of tension. 


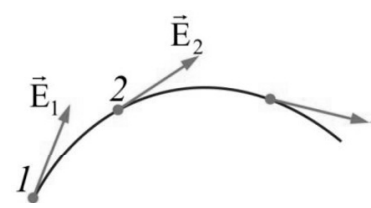

Figure 2. The lines of force of the electrostatic field (Fig. 3).

The power line is credited a certain direction - from the positive to the negative charge, or to infinity

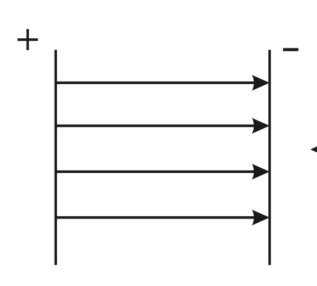

(a)

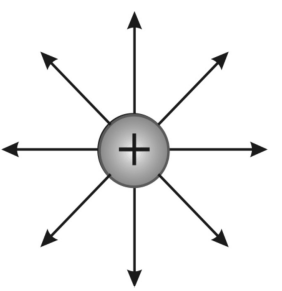

(b)

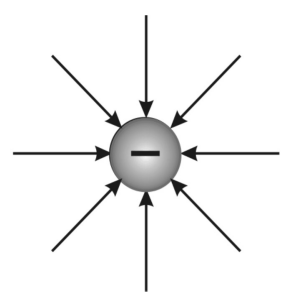

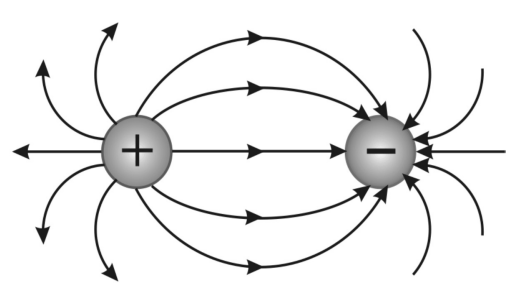

(c)

$a$ - uniform electrostatic field; $b$ - electrostatic field positive and negative charges; $c$ - electrostatic field of two opposite charges

Figure 3. The direction of the force lines of the electrostatic field

Concludes the study of electrostatics on the first stage of familiarity with the concept of the capacitor, its types and main characteristics (Fig. 4).

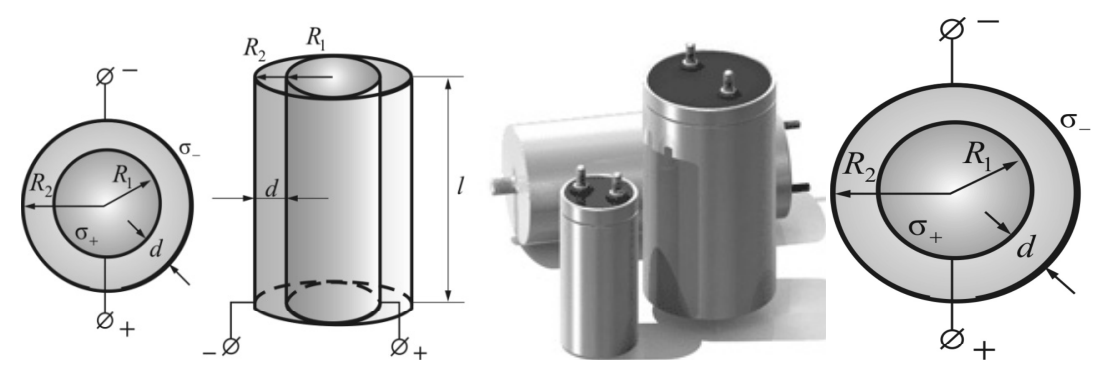

Figure 4. Types of capacitors

Selected and systematized relevant topic theoretical material studied in the second phase of training of pupils. The concept of flow strength, Gauss theorem, we study its application.

The lines penetrating element $S$, and $S_{0}$ penetrates the element, which is a projection of $S$ on a plane perpendicular to the vector of the $\vec{E}$ (Fig. 5) of the element. The flow field vector — scalar quantity. It can be both positive and negative [2].

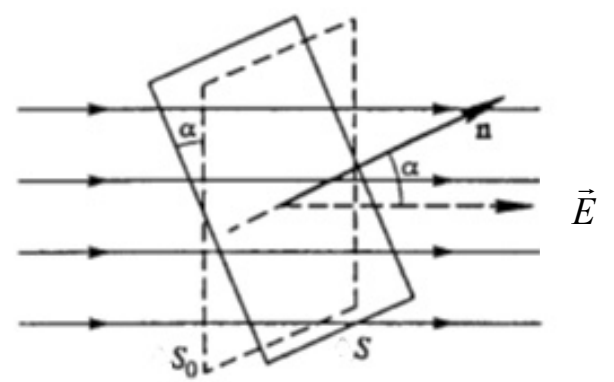

Figure 5. Determination of the flow of the vector field through the area $S$

We consider the electrostatic field in the presence of conductors and dielectrics, capacitors and connection types of energy charged capacitor. 
Electrical conductors - are substances that are well-conducting. A characteristic feature of the conductors that they always have a large number of free charge carriers, i.e. free electrons or ions (Fig. 6).

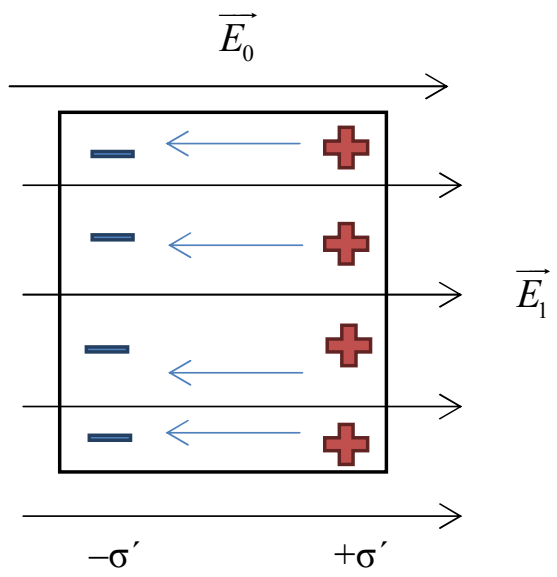

Figure 6. The electrical conductor placed in an external field

Due to the redistribution of charges in the conductor, it creates its own field strength $\vec{E}_{1} \uparrow \downarrow \vec{E}_{0}$. Therefore, this field strength inside the conductor $E=0$ and the potential is the same at all points (Fig. 7).

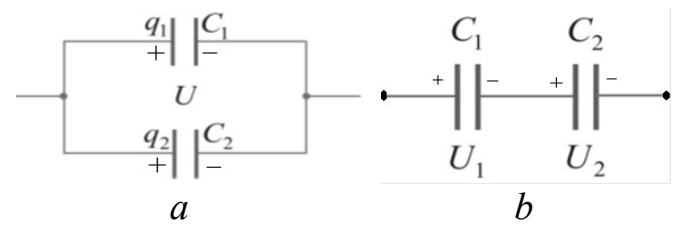

Figure 7. Parallel $(a)$ and series $(b)$ connection of capacitors

When placing a dielectric in an electric field does not occur directional traffic charges.

1. The intensity of the electric field inside the dielectric may not be equal to zero.

2. Bulk density of the charge in the insulator can be different from zero.

3. The tension lines are not perpendicular to the surface of the dielectric.

4. Different points of the dielectric may have a different capacity. Therefore, to talk about «the potential of the dielectric» is not necessary.

Offset electrical charges of matter under the influence of an electric field is called polarization. The ability for the polarization of the main properties of the dielectric (Fig. 8).

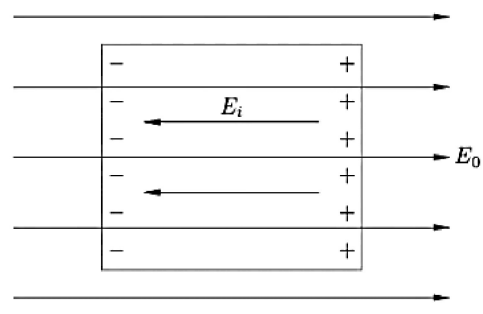

$a$

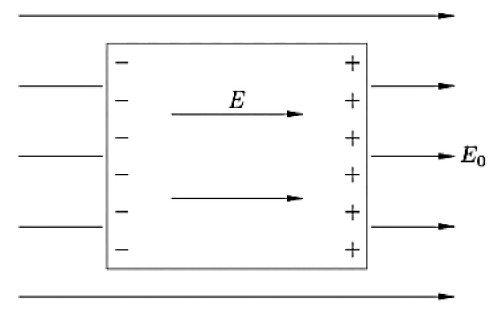

$b$

Figure 8 . The weakening of the field inside the dielectric

The polarization of the dielectric components comprises - electronic, ionic and orientation (dipole). Figure 9 illustrates polarization mechanisms of these kinds of [3]. 


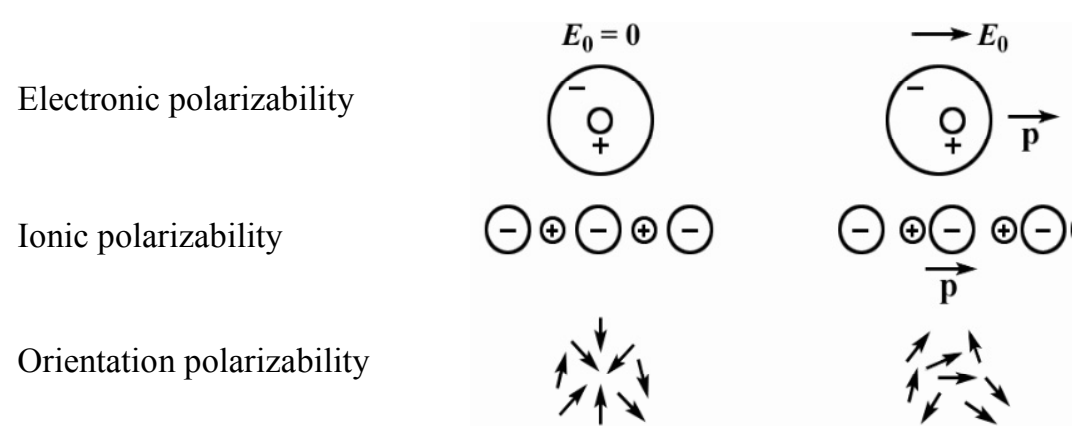

Figure 9. Polarization of dielectrics

It picks up on the theme and tested quality and experimental tasks, as well as the increased complexity of the problem. For example, select one of these tasks (Fig. 10, 11).

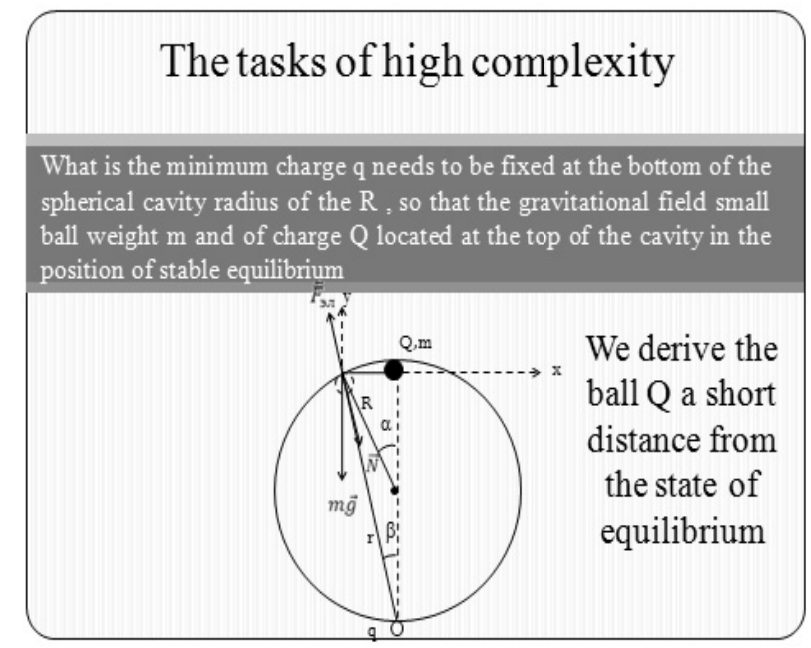

Figure 10. Graphical representation task

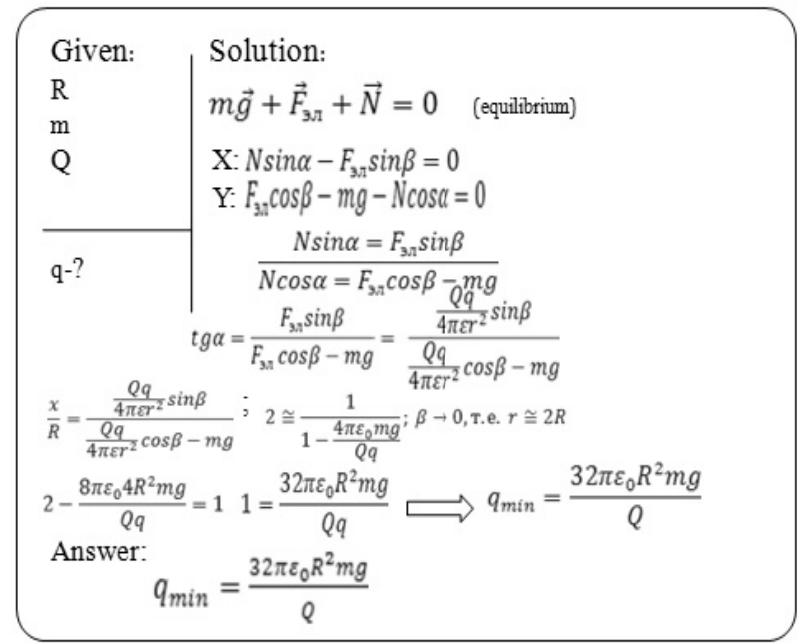

Figure 11. Solution of the task

It is known that the electrostatic field is often depicted with the help of the power lines. Suppose we define the intensity of a point lying on the boundary between two media: air $(\varepsilon=1)$ and water $(\varepsilon=81)$. At this point in 81 time decreases during the transition from air to water, the electric field intensity according to the formula $E=\frac{q}{4 \pi \varepsilon \varepsilon_{0}} / r^{2}$. If we neglect the water conductivity, then as many times will decrease the number of lines of force. When solving various problems in the calculation of fields because of the continuity of the vector tension $\vec{E}$ on the border between the media and dielectrics are certain inconveniences. To avoid them, we introduce a new vector $\vec{D}$, which is called electrostatic induction vector:

$$
\vec{D}=\varepsilon \varepsilon_{0} \vec{E} .
$$

You can now finalize the Gauss theorem: the flow of $N$ vector of the electrostatic field in a vacuum $E$ through any closed surface is proportional to the total charge $q$, located i.e. the flow vector of the inside surface of the electrostatic field through a closed surface can be found by the formula:

$$
N=\frac{q}{\varepsilon \varepsilon_{0}},
$$

where $\varepsilon$ - dielectric constant of the medium [4]. 
We apply the Gauss theorem (Fig. 12, 13).

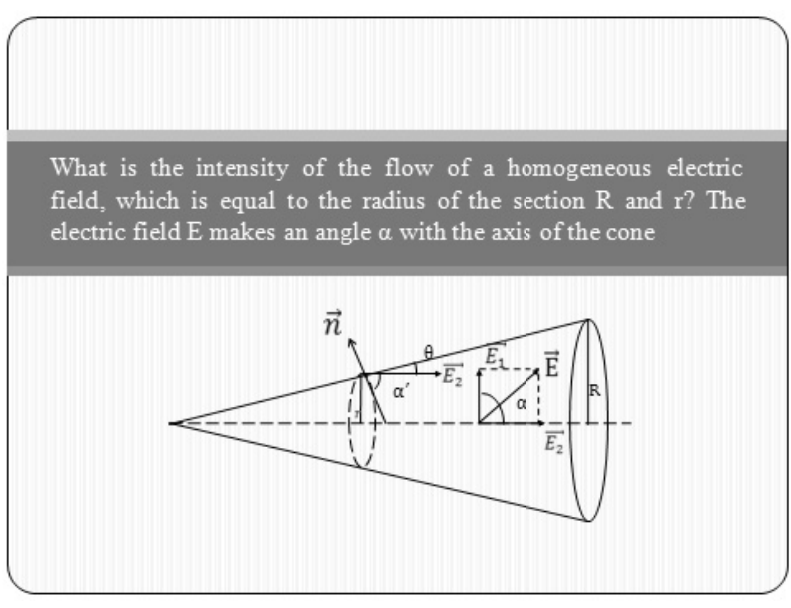

Figure 12. Graphical representation

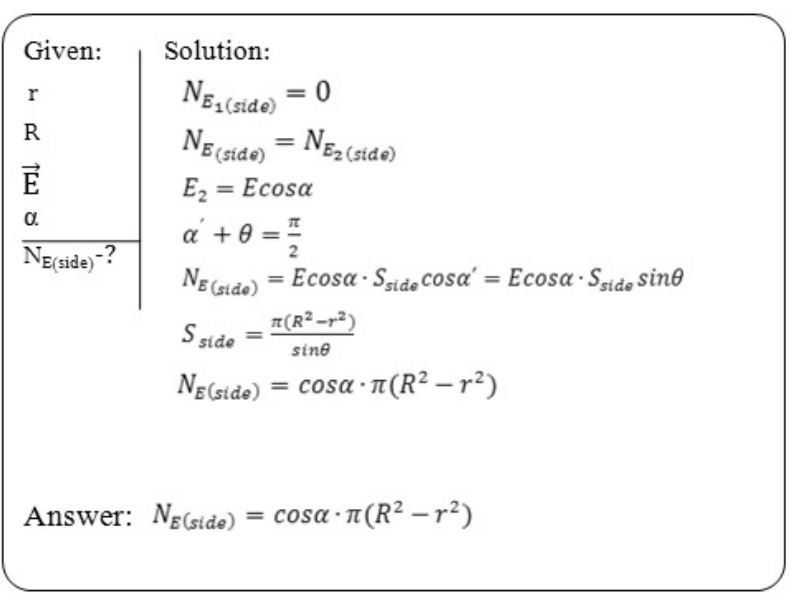

Figure 13. Solution of the task of the task

In the study section «Electrostatics» in high school should consider the following demonstration: electrification of dielectrics and conductors, the interaction of electrified bodies, structure and operation of the electrometer, the same name to obtain of opposite and equal charges when an electrifying charge distribution on the surface of the conductor, Coulomb's law, electric field lines, equipotential surfaces, the concept of electric capacity. The proposed demonstration in today's schools can be shown to students in the form of video clips.

Based on the above, we can make the following conclusions: physics.

1. The study of the topic «Electrostatics» is included in the mandatory training program for students of

2. Differences in the method of presentation of electrostatics on the first and second stages of the study are determined, first of all, the selection of the material content.

3. At the first stage of studying in the 8th grade students familiarize with basic concepts and simple enough on: electrification, charges species and their properties, electrostatic field, its main features and characteristics, tensions, potential capacitor. The number is theoretical familiarization character. In a number of the topics we studied not only the concept but also practiced the skills of application study of matter in practice, solving problems, such as Coulomb's law, electric capacity capacitors, electrostatic field strength, work and other.

4. In the second stage of the study of this subject in the 10th grade repetition is performed before the material studied in the 8th grade, and then repetition of those requiring more in-depth approach. We consider the increased complexity of the problem, a number of topics being studied for the first time. One such topic is, for example, the Gauss theorem - it is a hard material that requires careful study and time, but in spite of this consideration of the theorem in high school is necessary, because this largely improves the understanding of the physics and facilitates the solution of problems.

\section{References}

1 Кронгарт Б., Кем В. Физика: учебник для 10 кл. естеств.-мат. напр. общеобраз. шк. — Алматы: Мектеп, 2010. — $383 \mathrm{c}$.

2 Кравченко Н.С., Лисичко Е.В., Твердохлебов С.И. Физика 2. Электричество и магнетизм: учеб-метод. компл. Томск: Изд. Нац. исслед. Томск. политехн. ун-та, 2010. - $157 \mathrm{c.}$

3 Калашников С.Г. Электричество. - 6-е изд. - М.: Физматлит, 2003. - 624 с.

4 Тамм И.Е. Основы теории электричества. - М.: Физматлит, 2003. - 616 с. 


\title{
Л.Ф. Ильина, А.Б. Ишмухаметова \\ Электростатика мысалы негізінде қарапайым физика бағдарламасының ғылыми негіздері
}

\begin{abstract}
Мақалада мектеп оқушыларына физиканы оқытудың бірінші және екінші кезеңдерінде электростатиканы оқытудың әдістемесі ұсынылған. Білім беру сапасын арттыру үшін оқушының танымдық қызметін белсендіру және олардың танымдық қызығушылығын әзірлеудің кешенді әдістері мен құралдарын пайдалану қарастырылған.Тақырыпты жақсы және сапалы игеру үшін күрделігі жоғары есептер берілген. Интерактивті жабдықтарды қолдану берілген материалдың ұсынуын күшейтеді, оқушылардың қызығушылығы мен берілген материалдың есте сақтауын арттырады. Мақалада ұсынылған теориялық материалдың талдауы сыныпта шешілетін есептерге байланысты жаңа, дәстүрлі емес оқытуды ұйымдастыруға мүмкіндік береді.
\end{abstract}

\section{Л.Ф. Ильина, А.Б. Ишмухаметова \\ Научные основы элементарного курса физики на примере электростатики}

\begin{abstract}
В статье рассмотрена методика преподавания электростатики на первом и втором этапах обучения учащихся физике в школе. Для улучшения качества образования предложено использование в комплексе приемов и средств, активизирующих познавательную деятельность школьников и развивающих их познавательный интерес. Для лучшего и качественного усвоения темы даны задачи повышенной сложности. Применение интерактивного оборудования усиливает наглядность изложенного материала, повышает заинтересованность учащихся, позволяет улучшить запоминание учебного материала. Проведенный в статье анализ теоретического материала позволяет организовывать новые, нетрадиционные виды учебной деятельности в зависимости от решаемых на уроке задач.
\end{abstract}

\section{References}

1 Krongart B., Kem V. Physics. The textbook for grade 10 course natural and math. sciences in secondary schools, Almaty: Mektep, 2010, 383 p.

2 Kravchenko N.S, Lisichko E.V., Tverdokhlebov S.I. Physics 2. Electricity and magnetism, Educ.-method. complex, Tomsk: Tomsk Polytechnic University Publ., 2010, 157 p.

3 Kalashnikov S.G. Electricity, 6th ed., Moscow: Fizmatlit, 2003, 624 p.

4 Tamm I.E. Basics of theory of electricity, Moscow: Fizmatlit, 2003, 616 p. 